Doyle; The Fall: Albert Camus; Confessions of an English Opium Eater: Thomas De Quincey; The Glass Bead Game: Hermann Hesse; On the Road: Jack Kerouac; The Sailor who Fell from Grace with the Sea: Yukio Mishima.

\section{APPENDIX II: SPECIMEN Examination PAPER Literature and Psychiatry (Time allowed: 2 hours)}

Write an essay, using it to demonstrate your broad knowledge of matters pertaining to psychiatry, on one of the following:

1. With reference to Doctor Faustus in the book by Thomas Mann, discuss the relationship between intelligence and creativity.

2. 'Kill the pig! Cut his throat! Kill the pig! Bash him in!' The quotation is from William Golding's Lord of the Flies. Write an essay on natural violence. Use examples from the book. but do not necessarily limit your discussion to adolescent males.

3. Everybody has a good side and a bad side. Describe your thoughts on this statement in reference to R. L. Stevenson's book, Doctor Jekyll and Mr Hyde. Make particular mention of Jung's concepts of Archetypes and the Collective Unconscious.

4. 'Lawyers, I suppose, were children once.' (Charles Lamb, quoted by Harper Lee in To Kill a Mockingbird). Using examples from this book, describe in outline Eric Erikson's epigenetic view of the human life-cycle which includes eight stages or crises.

5. Discuss the notion that Flaubert's character, Madame Bovary, suffered from an hysterical personality disorder.

\section{DeAR SiRS}

\section{Effects of hospital inquiries}

In his review of Hospitals in Trouble (Bulletin, November 1984, 8, 221-22), Peter Kennedy claims that Professor Martin 'shatters' the case for the Scottish Mental Welfare Commission. What Martin does is to speculate on the effect such a body might have had in England and Wales over the past twenty years, and he concludes: 'There would have been fewer or even no scandals. But would things have been different? Or better?'

The impact of the inquiries in England and Wales has yet to be assessed. 'Some, including former members of inquiries, deplore the cost and anguish created by their proceedings' (p. 251), and Martin goes on to point out that in 'the early 1980s . . . there are still backward hospitals, poor staffing, deplorable facilities ... and specific instances of brutality' (p. 97).

It would be interesting to hear the views of people working in the hospitals concerned, especially in those mental handicap hospitals which experienced over 60 per cent of the total inquiries. As Martin says, 'The real tests are yet to follow.'

T. L. Pilkington

University of Leeds,

Department of Psychiatry,

15 Hyde Terrace, Leeds

\section{REFERENCE}

'Martin, J. P. (1984) Hospitals in Trouble. Oxford: Basil Blackwell.

\section{Self-damage in patients with Klinefelter's Syndrome}

DEAR SiRS

I would like to describe another case with marked similarities to those reported by Professor Priest and his colleagues (Bulletin, July 1984, 8, 140) and more recently by $\mathrm{Dr}$ Christian and $\mathrm{Dr}$ Thomas (Bulletin, November $1984,8,218$ ).

This patient is a 24-year-old single man, diagnosed as Klinefelter's Syndrome. He is tall, has gynaecomastia, atrophic testes and sparse bodily hair. His IQ is in the dull-normal range. He has a history of neurotic disturbance since childhood and a personality disorder with impulsive and aggressive behaviour which has resulted in wrist slashing on several occasions and damage to hospital property. His relationships are immature and dependent. He has had several short lived psychotic episodes, mainly with auditory hallucinations.

Interestingly, he has also had episodes of urinary retention which have required repeated catheterization, although there is no obvious neurological or urological problem.

His behaviour has resulted in several prolonged admissions and he remains a management problem.

NOREEN RAMSEY

St John of God Hospital,

Stillorgan, Co. Dublin

\title{
The Walk Papers
}

Dr Alexander Walk, who served the College so nobly as Associate Editor of the Journal, Honorary Librarian and Past-President of the RMPA was, in addition, a man of enormous scholarship. During his lifetime he collected a veritable mountain of notes and excerpts on psychiatric history.

Dr Walk died on 22 July 1982. His widow, Mrs Peggy Walk, has generously donated the collection to the College. Not only this, but she has produced an index to the col- lection which in itself is a masterpiece of scholarship.

The purpose of this brief note is to bring the attention of members of the College, and indeed, other scholars, to the existence of the collection and the index which I feel sure will prove invaluable as a source of information on psychiatric history and related subjects.

H. R. RoLLIN

Honorary Librarian 